\title{
Öğretmenlerin Çokkültürlü Eğitim Tutumunun Sosyal Zekâ Algısına Göre İncelenmesi
}

\section{The Investigation of Teachers' Multicultural Education Attitude According to the Perception of Social Intelligence}

\author{
Yener AKMAN ${ }^{*} \quad$ Gülşah IMAMOĞLU AKMAN ${ }^{* *}$
}

Öz. Bu araştırmanın amacı ilkokul, ortaokul ve lisede görev yapan öğretmenlerinin çokkültürlü eğitim tutum ve sosyal zekâ algılarının cinsiyet, eğitim düzeyi ve okul türü gibi çeşitli değişkenler açısından incelenmesi ve değişkenler arasında ilişkinin belirlenmesidir. Araştırmada ilişkisel tarama modeli kullanılmıştır. Çalışma, 2015-2016 eğitim-öğretim yılı içerisinde 318 öğretmen ile yürütülmüştür. Verilerin toplanmasında "Çokkültürlü Eğitim Tutum Ölçeği" ve "Sosyal Zekâ Ölçeği" kullanılmıştır. Araştırmada öğretmenlerin çokkültürlü eğitim tutum ve sosyal zekâ algıları görece yüksek düzeyde belirlenmiştir. Öğretmenlerin sosyal zekâ algıları cinsiyet, eğitim düzeyi ve okul türüne göre anlamlı farklıık göstermemektedir. Öğretmenlerin çokkültürlü eğitim tutum algıları ise okul türüne göre anlamlı farklılıklar göstermiştir. Ayrıca çokkültürlü eğitim tutumu ve sosyal zekâ arasında pozitif yönde görece düşük düzeyde anlamlı ilişkiler tespit edilmiştir. Ek olarak sosyal bilgi sürecinin çokkültürlü eğitim tutumunun anlamlı yordayıcısı olduğu saptanmıştır.

Anahtar Kelimeler: Öğretmen, sosyal zekâ, çokkültürlü eğitim, algı.

Abstract. The aim of this research is to analyse the perceptions of primary and secondary school teachers' about multicultural education and social intelligence according to various variables as gender, education level and school type and to determine the relationship between the variables. In the research relational modelhas been used. The study has been carried out with 318 teachers in 2015-2016 academic year. "Multicultural Education Attitude Scale" and "Social Intelligence Scale" is used for collecting the data. In the research, the perceptions of teachers' about multicultural education and social intelligence is relatively high level. There isn't significant relationship about social intelligence about gender, education level and school type. Also, there is significant differences about multicultural education about school type. In addition, it's identified that there is significant relatively low relationship between the perceptions of the multicultural education and social intelligence. Also, it's found that social information process is a significant predictor of the attitudes of multicultural education.

Keywords: Teacher, social intelligence, multicultural education, perception.
Toplumsal Mesaj. Bu araştırmanın amacı ilkokul, ortaokul ve lisede görev yapan öğretmenlerinin çokkültürlü eğitim tutum ve sosyal zekâ algılarının cinsiyet, eğitim düzeyi ve okul türü gibi çeşitli değişkenler açısından incelenmesi ve değişkenler arasında ilişkinin belirlenmesidir.

Public Interest Statement. The aim of this research is to analyse the perceptions of primary and secondary school teachers' about multicultural education and social intelligence according to various variables as gender, education level and school type and to determine the relationship between the variables.

\footnotetext{
* Öğretmen, Milli Eğitim Bakanlığı, yenerakman@yahoo.com

** Öğretmen, Milli Eğitim Bakanlığı, ankaragulsah@gmail.com
} 


\section{GíRiş}

Okullar, yirmi birinci yüzyılın son çeyreğinde göçler ve küreselleşmeden dolayı çok çeşitli bir yapıya bürünmüştür. UNESCO'ya (2004) göre, küresel ya da bölgesel göçler artarken, öğrenci çeşitliliği de büyümeye devam edecektir. Bu durum farklı etnik yapıların ve kültürlerin bulunduğu çokkültürlü bir dünyada, eğitim için çokkültürlü sınıfların varlığını ortaya çıkaracaktır. Goleman (2006), Sosyal Zekô isimli kitabında, çokkültürlü bir dünyada, çocukların mutlu büyümeleri ve barış içerisinde yaşayabilmeleri için ne yapılabileceğini ve insanların ne tür bir toplum oluşturabileceği sorularının cevaplarını aramıştır. Bu soruların cevabında ayrımcılığı göz ardı ederek, farkı insanların ilgi ve intiyaçlarını hisseden ve etkili iletişim becerilerine sahip sosyal zekâsı geliş̧miş bireylerin varlığı yatmaktadır. Bir diğer deyişle sosyal etkileşim ve kişiler arası ilişkiler vurgulanmaktadır. Chauhan'a (2016) göre, yirmi birinci yüzyılda sosyal zekâ, insanların iyi oluş hali ve herhangi bir meslekte başarılı olması için önemli bir bileşen olarak kabul görmektedir. İnsanlarla iyi ilişkiler kurabilme yeteneği olarak görülen sosyal zekâ, sosyal dinamikler üzerindeki farkındalığa işaret etmektedir. Bu doğrultuda küresel dünyada yaşanılan toplum içerisindeki sosyal dinamiklerin farkında olmak ve farklııklara yönelik çokkültürlü bir eğitim yaklaşımını benimsemek önem kazanmaktadır.

Sosyal zekânın bireyin kişiliği ve bireysel davranışlarıyla yakın ilişkili olduğunu belirten çalışmalar bulunmaktadır (Zirkel, 2000). Sosyal zekâsı gelişmiş olan bireyler yeterliliklerinin farkında olurken, aynı zamanda çevrelerini de anlayabilmektedir. Bu durum duygularını kontrol etmeyi ve amaçlarıyla ilgili daha etkili kararlar alabilmelerini sağlamaktadır. Aman ve Verma (2015) ise sosyal zekâyı, karmaşık sosyal ilişkiler ve çevre kapasitesi olarak tanımlamaktadır. Aynı zamanda sosyal zekâ; anlama, yönetme, ayarlama, sorunları çözme ve durumun gerektirdiği şekilde doğru ayarlamaları yapma becerisidir. Phipps'in (2007) araştırmasına göre, sosyal zekâ, iletişim ve yenileşmenin kavramları ile ilişkili olarak saptanmıştır. Çokkültürlü eğitimin gerektirdiği algılama ve farklı nitelikteki öğrencilerin intiyaçlarının karşılanmasında iletişim becerisini etkili kullanan sosyal zekâsı yüksek öğretmenler bu tür öğrencilerin sosyal uyum sürecini başarı ile atlatmalarına yardımcı olacakları belirtilebilir. Birçok araştırmacı ve pedagog, olumlu öğretmen-öğrenci etkileşiminin geliştirilmesi için öğretimde sosyal becerilerin kullanılmasının gerekliliğini ileri sürmektedir (Goodstein, 1984; Porter ve Brophy, 1988). Albrecht (2006) de öğretmenler için sosyal zekâyı bir ön koşul olarak düşünmektedir. Eğitim sistemi ve öğretmenlerin yüksek sosyal zekâ ile ilişkili davranışlarının teşvik edici uygulamaları desteklemesi gerektiği görüşündedir.

\section{1 Çokkültürlü Eğitim}

Çokkültürlü eğitim; dürüstlük, eşitlik, sosyal adalet ve eleştirel bilinç gibi demokratik unsurların toplumda yer edinmesini amaçlamaktadır. Türkiye'de 2005-2006 eğitim-öğretim yılında geçilen yapılandırmacı eğitim yaklaşımı ile öğrenciler eğitimin merkezine alınarak, onların intiyaçlarına odaklanılmıştır. Süreç içerisinde yapılandırmacı yaklaşımda içerik yönünden bazı değişimler gerçekleşmiş olmasına rağmen genel itibariyle uygulanmaya devam etmektedir. Bu yaklaşım ile çokkültürlülük ve farklılıklara saygı eğitim programlarında daha fazla vurgulanmaya başlamıştır. Geçmişten günümüze Türkiye'de çeşitli etnik kökenden ve dilden insanların yaşadıkları bilinmektedir. Ancak son yıllarda Türkiye'ye dış göç ile özellikle Suriye'den gelen sayıları milyonları bulan insanlarla karşılaşılmaktadır. Bunun sonucunda bir insan hakkı olan eğitime ihtiyaç duyan yüzbinlerce Suriyeli öğrenci Türkiye'de yaşamaya başlamıştır. Türkiye'de bulunan Suriyeli öğrencilerin çoğunluğu kamu okullarında Türkiye vatandaşlarıyla beraber eğitim görmektedir. Özellikle farklı dil, köken ve kültürel alt yapıdan gelen öğrenciler arasında uyumu sağlamak ve Türkiye özelinde Suriyeli öğrencilerin eğitim intiyaçlarını modern çağın gereklilikleri çerçevesinde karşılamak oldukça önemlidir. Bu doğrultuda öğretmenlerin eğitim yaklaşımlarının herkesi kapsayıcı bir nitelikte çokkültürlü eğitim anlayışı içerisinde olması faydalı olabilir. Destekler nitelikte Başbay ve Bektaş (2009) da farklı kültürel değerlere saygı duyan ve benimseyen bir neslin eğitim ile yetiştirilmesinin önemli olduğunu düşünmektedir.

Çokkültürlü eğitim uyum sürecinde eleştirel teorinin etkisinin olduğu görülmektedir (Brayboy, 2005). Nieto'ya (2000) göre, çokkültürlü eğitim, önyargıyı azaltma, ırkçllık ile mücadele ve 
reddetme, kapsamlı okul reformu ve tüm öğrenciler için temel eğitim ile ilişkilidir. Banks (1993a), çokkültürlü eğitimin okulları dönüştürmeye hizmet ettiğini savunmaktadır. Banks'e (1993a) göre, etnik ve ırksal farklılıkların olduğu dünyada, tüm öğrenciler gerekli bilgi, tutum ve becerileri kazanmalıdır. Araştırmacılar çokkültürlü eğitimin hedefleri arasında; toplumun göz ardı edilmiş üyelerine karşı ayrımcılığın ve önyargının azaltılması, herkesin eşit erişime ve sosyal adalete ulaşımı için çalışılması ve farklı kültürel gruplar arasında adil güç dağııııının sağlanması belirtilebilir (Banks, 2008; Sleeter ve Grant, 2003). Çokkültürlülük, farklılıklar içeren bir toplumda sosyo-kültürel ve duygusal uyuma ulaşmak için empati ve katılımı teşvik etmektedir.

Çokkültürlülük üzerine görüşler belirten uluslararası kuruluşlar arasında UNESCO da yer almaktadır. UNESCO'ya göre çokkültürlülügün temelinde farklı kültürlerin bir arada sosyalleşebilmesi yatmaktadır. Ayrıca küresel barış ve huzur ortamının, kültürel farklııklara saygı ve işbirliğinden geçtiği belirtilmektedir. İşbirliğinin ise eğitimsel uygulamalar çerçevesinde gerçekleştirilmesinin daha etkili olacağına inanılmaktadır (King, 2004). UNESCO, tüm toplumlardan insan hakları temelinde çeşitliliği savunmalarını, küresel vatandaşılı algısının yerleşmesini ve bu bilincin eğitim yoluyla geliştirilmesini önermektedir. Bu bağlamda bazı araştırmacılara göre çokkültürlü eğitim politikalarının ulus devletler üzerinde sorun oluşturabilme potansiyeli olduğu iddia edilmiştir. Ancak UNESCO, insan hakları temelinde potansiyel sorunların aşılabileceğinin altını çizmiştir.

Çeşitlilik ve çokkültürlülük zaman zaman birbirinin yerine kullanılabilen birbirleriyle ilgili kavramlar olarak belirtilebilir. Krishnamurti'ye (2003) göre tüm kültürel farklılıklara örnek teşkil eden çeşitlilik, çokkültürlülük kavramının önemli bir bileşeni olarak düşünülebilir. Ancak çokkültürlülük, çeşitlilikten çok daha fazlasını kapsamaktadır. Çokkültürlülük, farklı ırklardan, kültürden, dilden, dinden, cinsiyetten ve cinsel yönelimden olan tüm insanların çeşitliliğinin ve katılım konusunda fırsat eşitliğinin değerinin önemi göstermek istemektedir (Nieto, 2000). Çokkültürlü eğitim bir bakıma ırkçılık karşıtı eğitim hedefleriyle kültürel uyumun birleşiminin altını çizmektedir (Lund, 2006). Obiakor'a (2007) göre, çokkültürlü eğitimin, geleneksel ve özel eğitim üzerinde eşitleyici bir etkisi bulunmaktadır. Tüm öğrencilerinin potansiyellerini kültürel, dilsel, etnik ve sosyo-ekonomik farklııklarına rağmen en üst düzeye çıkarmayı amaçlamaktadır. Nieto'ya (2000) göre, çokkültürlü eğitim, okul ikliminin ve uygulamalarının içine işlemelidir. Banks (1991) tarafından çokkültürlü eğitimin boyutları; eğitimsel içeriğin uyumlu hale getirilmesi, bilgi yapım süreci, önyargıyı azaltma, adil eğitim hakkı ve okul kültürünün ve sosyal yapısının güçlendirilmesi olarak beş kavram çerçevesinde geliştirilmiştir. Eğitimsel içeriğin uyumlu hale getirilmesinde, öğretmenler; alanlarıyla ilgili anahtar kavramları, ilkeleri ve genellemeleri gösterirken çeşitli kültürler ya da gruplardan örnekler ve bilgiler aktarmaktadır. Bilgi yapımı boyutunda, öğretmenler; öğrencilerine bilginin nasıl oluşturulduğunu ve grupların ırksal, etnik ve sosyal sınıflarından nasıl etkilendiğini anlamaları için yardımcı olmaktadırlar. Önyargıyı azaltma boyutunda, öğrencilerin ırksal tutum ve stratejilerinin daha demokratik tutum ve değerlere dönüşmesi için yardımcı olunmaktadır. Adil eğitim hakkı boyutu ise öğretmenlerin farklı ırksal, etnik ve sosyal sınıflardan olan öğrencilerin akademik başarılarını kolaylaştırmak için uyguladıkları teknik ve yöntemleri vurgulamaktadır. Son olarak okul kültürü ve sosyal yapının güçlendirilmesi de okul kültürünün ve örgütünün yeniden yapılandırılarak farklı etnik, ırksal ve sosyal gruplardan olan öğrencilerin kaliteli eğitime ulaşabilmelerini göstermektedir.

Tarihsel süreç içerisinde çokkültürlü eğitimin gelişimi incelendiğinde ezilen çeşitli grupların sivil haklar hareketine kadar uzanmaktadır. Çokkültürlü eğitim tarihi 1960'lardaki sivil haklar mücadelesi zamanında kamu kurumlarındaki ayrımcı uygulamalarla karşılaşan Afrikalı Amerikalılar ve diğer renklerden olan insanların sosyal eylemlerine kadar gitmektedir (Davidman ve Davidman, 1997). 1960'ların sonu ve 1970'lerin başında ise kadın hakları hareketi eğitim reformu için yönlendirici bir eylem olarak ortaya çıktı. Kadın hakları savunucuları istihdam ve eğitimsel fırsatlardaki eşitsizlikler mücadele ettiler (Banks, 1989). 1980'li yıllarda çokkültürlü eğitime yönelik akademik çalışmalar yoğunluk kazandı. Eşit eğitim fırsatı ve okul dönüşümü ve sosyal değişim arasında daha derin ve yeni yapılar geliştirildi. Günümüzde ise çokkültürlü eğitim, 
yeni eğitim yaklaşımları ve modelleri geliştirilmesi ile sosyal adalet, eleştirel düşünme ve fırsat eşitliği mücadelesine odaklanmaktadır.

Çokkültürlü eğitim üzerine gerçekleştirilen çalışmalar incelendiğinde son yıllarda Türkiye'de ilgi çeken bir konu olduğu görülmektedir. Özdemir ve Dil'in (2013), lise öğretmenlerinin çokkültürlü eğitime yönelik tutumlarını inceledikleri çalışmalarında cinsiyet, eğitim düzeyi, medeni durum, mesleki kıdem ve sendika üyeliğine göre farklılık göstermediğini, eğitim ve fen-edebiyat fakültesi mezunlarının teknik eğitim fakültesinden mezun olanlara göre yüksek düzeyde anlamlı farkılık gösterdiğini tespit etmişlerdir. Tortop (2014) ise öğretmenlerin üstün yetenekliler eğitimi ve çokkültürlü eğitim tutumunu irdelediği araştırmasında kavramlar arasında orta düzeyde anlamlı bir ilişki saptamıştır. Günay, Aydın ve Koç Damgacı (2015) da, eğitim fakültelerinde çalışan akademisyenlerin çokkültürlü eğitim tutumlarını metaforlar aracıllğı ile incelemişlerdir. Araştırmalarında akademisyenlerin çokkültürlü eğitime yönelik olumlu tutum gösterdikleri ve kavramın tanımlanmasında en çok "gökkuşağı" ve "mozaik" mecazlarının kullanıldığı görülmüştür. Ayrıca kavramın özel eğitim (Irvine, 2012; Obiakor, 2007), kültürlerarası eğitim (Gorski, 2006), sosyal adalet (Kumagai ve Lypson, 2006; Santamaria, 2014), üstün yetenekliler eğitimi (Tortop, 2014), eşitlik (Santamaria, 2014) gibi kavramlarla ilişkisinin araştııılığı çalışmalar da gerçekleştirilmiştir. Çokkültürlü eğitim ile ilgili olduğu düşünülen bir kavram da sosyal zekâ olarak belirtilebilir.

\subsection{Sosyal Zekâ}

Sosyal zekâ üzerine psikoloji alan yazınında çok geniş bir çalışma alanı bulunmaktadır. Genel yaklaşım sosyal zekânın bir kişilik özelliği olduğu doğrultusundadır. Bazı insanlar diğer bireyleri anlama ve ilişki kurma açısından başarılıyken, bazıları da önemli zorluklarla karşılaşabilmektedir. Ancak sosyal zekânın özellikleri ve yansımaları tam ve net olarak belirlenememiştir. Bunun önemli nedenlerinden birisi, sosyal zekânın karşılaşılan duruma göre çok farklı yollarla açıklanmasıdır (Markopoulos, Ruyter, Privender ve Breemen, 2005). Aman ve Verma'ya (2015) göre sosyal zekâ, uyumlu sosyal etkileşimlerde bütünleşme becerisi olarak nitelendirilmektedir.

Sosyal zekânın, sosyal bilinç ve ilişki yönetimi ile yakından ilişkili olduğu düşünülmektedir. Ayrıca duygusal (Goleman, 1995) ve kişilerarası zekâ (Hatch ve Gardner, 1993) da sosyal zekâ ile kısmen örtüşen kavramlar olarak görülmektedir. Thorndike'a (1920) göre, sosyal zekâ, insanları anlama, yönetme ve insan ilişkilerinde akıllıca hareket etme becerisidir. Dong, Koper ve Collaço (2008) ise, sosyal zekânın uzun süre problem çözme yeteneği, liderlik ve olumlu duygusal deneyimlerle ilişkili olduğunu belirtmiştir. Goleman'a (2006) göre, sosyal zekâ, dünyada iyi yaşamak için gereken tüm beceriler olarak tanımlanmaktadır. Albrecht (2006) ise, sosyal zekâyı, başkaları ile iyi geçinebilme ve işbirliği için ikna edebilme yeteneği olarak açıklamaktadır. Ayrıca insanların zarar verici ve geliştirici şekilde davrandıklarını belirtmiştir. Zarar verici davranışlar sergileyenlerin diğer insanları sinirli ve üzgün bir hale getirirken, geliştirici bir tutum içerisinde olanların insanları cesaretlendirdiği ifade edilmektedir. Zarar verici davranışların sürekliliği düşük düzeyde sosyal zekâyı, geliştirici davranışların devamlılığı ise yüksek düzeyde sosyal zekâyı işaret etmektedir. Sosyal zekâ çatışmayı azaltırken işbirliği meydana getirmektedir. Dar kafalıık ve kutuplaşmayı, anlayışa dönüştürmektedir. Markopoulos ve diğerlerine (2005) göre, sosyal yönden zeki davranışlar nazik olmaktan etkileşime, hatalarını kabul etmekten, merak göstermeye ve karşısındakileri sözsüz olarak anlayabilme becerisine kadar çeşitli özellikler göstermektedir.

Değinilen tanımlar göz önünde bulundurulduğunda sosyal zekâ kavramını üzerinde hem fikir olunan bir tanım olmadığını belirtmek uygun olacaktır. Ancak 1900'lü yılların başından bu yana ilgi çeken kavram üzerindeki soru işaretleri sadece tanımı değil, ayrı bir zekâ türü olup olmadığı, boyutları ve ölçülmesi konusunda da süregelmiştir. Sosyal zekâ kavramı hakkındaki ilk çalışmalarda bilişsel (bireylerin iç dünyasını fark etme) ve davranışsal (insanları yönlendirebilme) olmak üzere iki boyut üzerinde durulmuştur. Marlowe (1986) ise, sosyal ilgi, sosyal kendine yeterlik, empati yeteneği ve sosyal performans yeteneği olarak boyutlandırmıştır. Süreç içerisinde Kosmitski ve John (1993), Silberman (2000), Buzan (2002), Goleman (2006) da sosyal zekâ kavramı 
boyutlarına çeşitli sınıflandırmalar kazandırmışlardır. Bu araştırmada sosyal zekâ, Silvera, Martinussen ve Dahl (2001) ortaya koydukları sosyal bilgi süreci, sosyal yetenek ve sosyal farkındalık olmak üzere üç boyutlu yapı çerçevesinde incelenmiştir. Sosyal zekânın genel zekânın bir parçası olduğunu kabul eden araştırmacılar, genel zekânın sosyal olaylara uygulanması olarak ifade etmişlerdir. Ancak günümüzde ise karşılıklı etkileşim içerisinde olan farklı zekâ türleri olduğu kanısı güçlenmektedir (Lee, 1999). Sosyal zekânın ölçülmesi konusunda geliştirilen ölçeklerde ise ilk çalışmalar bireyin bilişsel özelliklerine odaklanırken süreç içerisinde başkalarının değerlendirmelerinden kendini değerlendirmeye kadar çeşitli ölçekler hazırlanmıştır (Kaukainen, Bjorkqvist, Lagerspetz, Osterman, Salmivalli ve Rothberg, 1999). Kavram üzerinde uzun yıllardır çalışılmasına rağmen gerek tanımlanması gerekse ölçülmesi noktalarında süren bir belirsizliğin olduğu görülmektedir.

Alan yazın incelendiğinde sosyal zekâ ile benlik saygısı (Doğan, Totan ve Sapmaz, 2009) ve sosyal zekâ ile kültürel zekâ (illhan ve Çetin, 2014) arasındaki ilişkinin araştırıldığı çalışmalarda kavramlar arasında anlamlı farklılıklar olduğu tespit edilmiştir. Ayrıca, Hançer ve Tanrısevdi'nin (2003) çalışmasında da empati ve performans arasındaki ilişkiyi kavramsal bir araştırma ile irdelenmiştir. Yabancı alan yazında kavram üzerine gerçekleştirilen çok daha fazla çalışma ile karşılaşılmıştır. Bu çalışmalarda sosyal zekânın; ebeveyn-çocuk iletişimi (Wallenius, Punamaki ve Rimpel, 2007), iş doyumu (Yahyazadeh-Jeloudar ve Lotfi-Goodarzi, 2012), üst-biliş (Aman ve Verma, 2015), kişilik özellikleri (Birknerová, Frankovský, Zbihlejová, 2013), duygusal zekâ (Birknerová, 2011; Emmerling ve Boyatzis, 2012), kültürlerarası eğitim (Latsone, 2013), liderlik (Zaccaro, Gilbert, Thor ve Mumford, 1991) gibi çeşitli kavramlarla olan ilişkisi incelenmiştir. Alan yazında mevcut araştırmada incelenen kavramların ilişkisini araştıran herhangi bir çalışmaya rastlanılmamıştır. Özellikle kişiler arası ilişkinin kalitesini belirlediği görülen sosyal zekânın, çokkültürlü eğitim tutumunu anlamlı şekilde etkiyen bir değişken olabileceği düşünülmektedir.

Öğretmenlerin çokkültürlü eğitim tutumu ve sosyal zekâ algılarının araştırıldığı bu çalışmada aşağıdaki soruların yanıtları aranmıştır:

1. Öğretmenlerin sosyal zekâ algıları cinsiyet, eğitim düzeyi ve okul türü değişkenlerine göre anlamlı farklılık göstermekte midir?

2. Öğretmenlerin çokkültürlü eğitim tutumu algıları cinsiyet, eğitim düzeyi ve okul türü değişkenlerine göre anlamlı farklılık göstermekte midir?

3. Öğretmenlerin sosyal zekâ ve çokkültürlü eğitim tutumu algıları arasında anlamlı bir ilişki var mıdır?

4. Öğretmenlerin sosyal zekâ algıları çokkültürlü eğitim tutumu algılarının anlamlı bir yordayıcısı mıdır?

\section{YÖNTEM}

Bu araştırma tarama ve ilişkisel tarama modelinde desenlenmiştir. Öğretmenlerin kavramlara yönelik algı düzeylerini saptamak için tarama ve kavramlar arasındaki ilişkiyi irdelemek için de ilişkisel tarama modeli tercih edilmiştir. Karasar (1994) ilişkisel tarama modellerini, "iki ve daha çok sayıdaki değişken arasında birlikte değişim varlığını ve/veya derecesini belirlemeyi amaçlayan araştırma modelleridir" biçiminde açıklamaktadır. Araştırmanın bağımlı değişkeni çokkültürlü eğitim tutumu ve bağımsız değişkenleri olarak sosyal zekâ ve boyutları belirlenmiştir.

\section{1 Çalışma Grubu}

Araştırma verileri 2015-2016 eğitim-öğretim yılı içerisinde 318 ilköğretim ve ortaöğretim öğretmeninden elde edilmiştir. Araştırmada örneklem belirlemesi yapılmamış çalışma grubu üzerinde gerçekleştirilmiştir. Araştırma verileri e-posta, sosyal paylaşım siteleri ve forum sitelerinden internet ortamında elde edilmiştir. Araştırmanın çalışma grubunu oluşturan öğretmenlerin; 202'si (\% 63.5) erkek ve 116'sı (\% 36.5) kadındır. Ayrıca öğretmenlerin 267'si lisans 
eğitim mezunu (\% 84) ve 51'i (\% 16) de lisansüstü eğitim mezunu iken 76'sı (\% 23.9) ilkokulda, 158'i (\% 49.7) ortaokulda ve 84'ü (\% 26.4) de lisede görev yapmaktadır.

\subsection{Veri Toplama Araçları}

Araştırmada yararlanılan veri toplama aracı üç bölümden oluşmaktadır. ilk bölümde, öğretmenlerin cinsiyet, eğitim düzeyi ve okul türü gibi demografik bilgileri toplanmıştır. İkinci bölümde, öğretmenlerin sosyal zekâ algılarının belirlenmesi için Tromso Sosyal Zekâ Ölçeği ve üçüncü bölümde, öğretmenlerin çokkültürlü eğitim tutumunun ölçülmesi amacıyla çokkültürlü Eğitim Tutum Ölçeği kullanılmıştır. Ölçeklerle ilgili ayrıntılı bilgiler aşağıda sunulmuştur:

Tromso Sosyal Zekâ Ölçeği: Ölçek, Doğan ve Çetin (2009) tarafından uyarlanıp geçerlik ve güvenilirliği yapılan 21 maddeden oluşan beşli likert türünde bir veri toplama aracıdır. Ölçek; sosyal bilgi süreci, sosyal beceri ve sosyal farkındalık boyutlarını içermektedir. Ölçeğin toplam Cronbach-Alfa güvenirlik katsayısının .83 , sosyal bilgi sürecinin .76, sosyal becerinin .83 ve sosyal farkındalığın .71 olduğu ölçülmüştür. Ayrıca boyutların toplam varyansın \% 44.79'unu açıladığı saptanmıştır. Mevcut araştırma verileri doğrultusunda güvenirlik ve geçerlik analizleri tekrar edilmiştir. Toplam güvenirlik katsayısı .79 ve üç boyutun açıkladığı toplam varyans ise $\% 43.72$ olarak hesaplanmıştır. Geçerlilik düzeyini tespit etmek için yapılan doğrulayıcı faktör analizi (DFA) sonucunda $\mathrm{GFI}=.85, \mathrm{AGFI}=.80, \mathrm{RMR}=.08, \mathrm{IFI}=.86, \mathrm{CFI}=.86, \mathrm{NFI}=.81, \chi 2=842.08, \mathrm{sd}=186, \chi 2 / \mathrm{sd}=4.52$ ve RMSEA=.08 değerleri elde edilmiştir. Analiz değerlerine göre S11-S8, S15-S2 ve S16-S12 maddeleri arasında modifikasyon yapılması uygun görülmüştür. Modifikasyon sonucunda, yeni değerler, $\mathrm{GFI}=.89, \mathrm{AGFI}=.85, \mathrm{RMR}=.06, \mathrm{IFI}=.91, \mathrm{CFI}=.91, \mathrm{NFI}=.85, \chi 2=616.31, \mathrm{sd}=183, \chi 2 / \mathrm{sd}=3.36$ ve RMSEA $=.06$ olarak ölçülmüştür. Bir bütün olarak değerler incelendiğinde ilk analize göre ikinci analizin geçerlik değerlerinin daha uyumlu olduğu belirtilebilir. Aritmetik ortalamaların yorumlanmasında; 1.00-1.80: "Çok düşük", 1.81-2.60: "Düşük", 2.61-3.20: “Orta", 3.21-4.20: "Yüksek" ve 4.21-5.00: “Çok yüksek" olarak kabul edilmiştir.

Çokkültürlü Eğitim Tutum Ölçeği: Yazıcı, Başol ve Toprak (2009) tarafından uyarlanan ölçek likert türünde 20 maddeden oluşmaktadır. Faktör analizine göre ölçek beş boyuttan meydana gelmektedir. Ancak birinci faktörün özdeğerinin çok yüksek olması ve tek faktörlü kullanımı destekleyen analizler sonucunda ölçek tek faktör olarak değerlendirilmiştir. Ayrıca ölçekte bulunan iki maddenin Türkiye bağlamında ölçmeye uygun olmadığı düşünüldüğünden ilgili maddeler ölçekten çıkartılarak 18 madde olarak belirlenmiştir. Ölçeğin toplam Cronbach-Alfa güvenirlik katsayısı .75 olarak hesaplanmıştır. Mevcut araştırma verilerine göre güvenirlik ve geçerlik analizleri tekrarlanmıştır. Ölçeğin Cronbach-Alfa güvenirlik katsayısı .86 olarak tespit edilmiştir. Geçerlik, DFA ile incelenmiştir. Illk analizde, $\chi 2=554.41 ; \mathrm{sd}=135, \chi 2 / \mathrm{sd}=4.10, \mathrm{AGFI}=.79$, $\mathrm{GFI}=.84, \mathrm{NFI}=.90, \mathrm{CFI}=.91, \mathrm{IFI}=.91, \mathrm{RMR}=.09$ ve RMSEA=.09 olarak hesaplanmıştır. Modifikasyon değerlerine dikkat edildiğinde bazı maddeler arasında modifikasyon yapma gerekliliği görülmüştür. Ç15-Ç16, Ç1-Ç2 ve ç17-Ç18 maddeleri arasında modifikasyon yapılmıştır. Modifikasyon oluşturulduktan sonra uyum indekslerde iyileşme saptanmıştır. Maddelerin hata varyansları arasında yapılan üç modifikasyondan sonra $\chi 2=376.38, \mathrm{sd}=132, \chi 2 / \mathrm{sd}=2.85, \mathrm{AGFI}=.85$, $\mathrm{GFI}=.88, \mathrm{NFI}=.93, \mathrm{CFI}=.95, \mathrm{IFI}=.95, \mathrm{RMR}=.07$ ve $\mathrm{RMSEA}=.07$ uyum iyiliği sonuçları elde edilmiştir. Analiz bir bütün olarak değerlendirildiğinde, çokkültürlü eğitim tutum ölçeğinin tek faktörlü yapısının bu araştırmada kullanılabileceği görülmüştür. Aritmetik ortalamaların yorumlanmasında; 1.00-1.80: “Çok düşük", 1.81-2.60: “Düşük", 2.61-3.20: “Orta”, 3.21-4.20: “Yüksek" ve 4.21-5.00: “Çok yüksek" olarak kabul edilmiştir.

\subsection{Verilerin Analizi}

Araştırma verilerinin çözümlenmesinde SPSS 22.0 ve Lisrel 8.8 paket programları kullanılmıştır. Araştırmada aritmetik ortalama, standart sapma, frekans gibi betimsel analizler gerçekleştirilmiştir. Kavramların demografik değişkenlere göre anlamlı farklılık oluşturup oluşturmadığı bağımsız gruplar için t-testi ve ANOVA, kavramlar arası ilişkinin tespit edilmesinde korelasyon analizi ve yordama düzeyini belirlemek için de çoklu doğrusal regresyon analizi yapılmıştır. Ayrıca elde edilen verilerin anlamlılı̆ı $p<.05$ ve $p<.01$ düzeyinde incelenmiştir. 


\section{BULGULAR}

\subsection{Sosyal Zekâ Düzeyinin Çeşitli Değişkenler Açısından İncelenmesi}

Sosyal zekâ düzeyinin cinsiyet ve eğitim düzeyi açısından incelenmesine yönelik t-testi ve tek yönlü varyans analizi (ANOVA) sonuçları Tablo 1 ve Tablo 2'de verilmiştir.

Tablo 1. Cinsiyet ve Eğitim Düzeyi Değişkenlerine Göre T-Testi Sonuçları

\begin{tabular}{llcccccc}
\hline Değişkenler & Gruplar & $\mathrm{n}$ & $\bar{X}$ & ss & sd & $t$ & $p^{*}$ \\
\hline Cinsiyet & Kadın & 202 & 3.67 & .41 & 316 & -.723 & .47 \\
& Erkek & 116 & 3.70 & .35 & & & \\
\hline Eğitim düzeyi & Lisans & 267 & 3.67 & .39 & 316 & -1.643 & .10 \\
& Lisansüstü & 51 & 3.77 & .40 & & &
\end{tabular}

$\star_{\mathrm{p}}<.05$

Tablo 1'de görüldüğü üzere, erkek öğretmenlerin ( $\bar{X}=3.70)$ sosyal zekâ algıları kadın öğretmenlerin ( $\bar{X}=3.67)$ algılarından daha yüksek ve lisansüstü eğitim alan öğretmenlerin ( $\bar{X}=3.77)$ algıları da lisans eğitimi alan öğretmenlerden ( $\bar{X}=3.67)$ daha yüksek olmasına rağmen anlamlı bir farklılık tespit edilmemiştir. Buna göre, sosyal zekâ algıları cinsiyet $\left[t_{(316)}=-.723, p<.05\right]$ ve eğitim düzeyi $\left[t_{(316)}=-1.643, p<.05\right]$ değişkenlerine göre anlamlı bir farklııık göstermemektedir.

Tablo 2. Okul Türü Değişkenine Göre ANOVA Sonuçları

\begin{tabular}{llccccccc}
\hline Değişkenler & Gruplar & $\mathrm{n}$ & $\bar{X}$ & ss & ss & $\mathrm{F}$ & $p^{*}$ & Anlamlı fark \\
\hline Okul türü & ilkokul & 76 & 3.76 & .36 & $3-314$ & 1.932 & .14 & \\
& Ortaokul & 158 & 3.66 & .38 & & & & \\
& Lise & 84 & 3.66 & .43 & & & & \\
& & & & & & &
\end{tabular}

\section{${ }^{*} \mathrm{p}<.05$}

Tablo 2 incelendiğinde ilkokulda görev yapan öğretmenlerin $(\bar{X}=3.76)$ sosyal zekâ algılarıortaokul $(\bar{X}=3.66)$ ve lisede $(\bar{X}=3.66)$ görev yapan öğretmenlerden daha yüksek görülmektedir. Buna rağmen okul türü değişkenine göre anlamlı farklılık saptanmamıştır $\left[F_{(3-314)}=1.932 ; p<.05\right]$.

\section{2 Çokkültürlü Eğitim Tutum Düzeyinin Çeşitli Değişkenler Açısından İncelenmesi}

Çokkültürlü eğitim tutum düzeyinin cinsiyet ve eğitim düzeyi değişkenleri açısından incelenmesine yönelik t-testi ve tek yönlü varyans analizi sonuçları Tablo 3 ve Tablo 4'te verilmiştir.

Tablo 3. Cinsiyet ve Eğitim Düzeyi Değişkenlerine Göre T-Testi Sonuçları

\begin{tabular}{llcccccc}
\hline Değişkenler & Gruplar & $\mathrm{n}$ & $\bar{X}$ & ss & sd & $t$ & $p^{*}$ \\
\hline Cinsiyet & Kadın & 202 & 3.70 & .50 & 316 & -1.720 & .08 \\
& Erkek & 116 & 3.82 & .66 & & & \\
\hline Eğitim düzeyi & Lisans & 267 & 3.73 & .58 & 316 & -.901 & .36 \\
& Lisansüstü & 51 & 3.81 & .48 & & & \\
\hline
\end{tabular}

Tablo 3'de görüldüğü üzere, erkek öğretmenlerin ( $\bar{X}=3.82)$ çokkültürlü eğitim tutum algıları kadın öğretmenlerin $(\bar{X}=3.70)$ algılarından daha yüksek ve lisansüstü eğitim alan öğretmenlerin $(\bar{X}=3.81)$ algıları da lisans eğitimi alan öğretmenlerden $(\bar{X}=3.73)$ daha yüksek olmasına rağmen anlamlı bir farklılık tespit edilmemiştir. Buna göre, çokkültürlü eğitim tutum algıları cinsiyet $\left[t_{(316)}=-\right.$ $1.720, p<.05]$ ve eğitim düzeyi $\left[t_{(316)}=-.901, p<.05\right]$ değişkenlerine göre anlamlı bir farklılık göstermemektedir. 
Tablo 4. Okul Türü Değişkenine Göre ANOVA Sonuçları

\begin{tabular}{llccccccc}
\hline Değişkenler & Gruplar & $\mathrm{n}$ & $\bar{X}$ & $\mathrm{Ss}$ & $\mathrm{Sd}$ & $\mathrm{F}$ & $p^{*}$ & Anlamlı fark \\
\hline Okul türü & illkokul & 76 & 4.11 & .63 & $3-314$ & 26.209 & $.00^{*}$ & illkokul-Ortaokul \\
& Ortaokul & 158 & 3.68 & .46 & & & & illkokul-Lise \\
& Lise & 84 & 3.53 & .53 & & & & \\
\hline
\end{tabular}

${ }^{\mathrm{p}}<.05$

Tablo 4 incelendiğinde ilkokulda görev yapan öğretmenlerin $(\bar{X}=4.11)$ çokkültürlü eğitim tutum algıları ortaokul $(\bar{X}=3.68)$ ve lisede $(\bar{X}=3.53)$ görev yapan öğretmenlerden daha yüksek görülmektedir. ANOVA sonucuna göre okul türü değişkenine göre anlamlı farklılıklar saptanmıştır $\left[F_{(3-314)}=26.209 ; p<.05\right]$. Farklılıkların hangi gruplar arasında olduğunu belirlemek için Scheffe testi uygulanmıştır. Test sonuçlarına göre, ilkokulda görev yapan öğretmenlerin çokkültürlü eğitim tutumları ortaokul ve lisede görev yapanlara göre anlamlı biçimde yüksek olarak tespit edilmiştir.

\section{3 Çokkültürlü Eğitim Tutumu Ve Sosyal Zekâ Kavramları Arasındaki iliş̧inin İncelenmesi}

Çokkültürlü eğitim tutumu ve sosyal zeka alt boyutlarının çeşitli istatistiki verileri ve değişkenler arasındaki ilişkinin incelenmesine yönelik aritmetik ortalama, standart sapma ve korelasyon analizi sonuçları Tablo 5'de verilmiştir.

Tablo 5. Ortalama ve Standart Sapma Değerleri ile Değişkenler Arasındaki Illişkiler

\begin{tabular}{lccccccc}
\hline Değişkenler & $\bar{X}$ & Ss & 1 & 2 & 3 & 4 & 5 \\
\hline 1.Çokkültürlü eğitim & 3.75 & .56 & - & $.21^{* *}$ & $.23^{* *}$ & $.12^{* *}$ & $.11^{* *}$ \\
2.Sosyal zekâ & 3.68 & .39 & & - & $.71^{* *}$ & $.75^{* *}$ & $.73^{* *}$ \\
3.Sosyal bilgi süreci & 3.70 & .48 & & & - & $.32^{* *}$ & $.23^{* *}$ \\
4.Sosyal beceri & 3.68 & .59 & & & & - & $.37^{* *}$ \\
5.Sosyal farkındalık & 3.66 & .54 & & & & - \\
\hline$* *$ p $<.01$ & & & & & & &
\end{tabular}

Tablo 5 incelendiğinde, öğretmenlerin sosyal zekâ ( $\bar{X}=3.68)$ ve çokkültürlü eğitim tutumu $(\bar{X}=3.75)$ düzeyleri görece yüksek olarak saptanmıştır. Sosyal zekâ boyutları arasında ise öğretmenlerin algı düzeylerinin görece en yüksek olduğu boyutun sosyal bilgi süreci $(\bar{X}=3.70)$ olduğu görülmektedir. Boyutlar arasındaki ilişkiler incelendiğinde, çokkültürlü eğitim tutumunun sosyal zekâ ve boyutları ile pozitif yönde düşük düzeyde anlamlı ilişkiler gösterdiği saptanmıştır. Çokkültürlü eğitim tutumu ile sosyal zekâ boyutları arasındaki en güçlü ilişkinin sosyal bilgi süreci $(r=.23, p<.01)$ ile olduğu belirlenmiştir.

\section{4 Çokkültürlü Eğitim Tutumunun Yordanması}

Çokkültürlü eğitim tutumunun sosyal zekâ boyutları tarafından yordanmasına ilişkin çoklu regresyon analizi sonuçları Tablo 6'da gösterilmektedir.

Tablo 6. Çokkültürlü Eğitim Tutumunun Yordanmasına Illişkin Çoklu Regresyon Analizi Sonuçları

\begin{tabular}{llccccc}
\hline Bağımlı Değişken & $\begin{array}{l}\text { Bağımsız } \\
\text { Değişkenler }\end{array}$ & B & Standart Hata B & $\beta$ & $t$ & $p^{*}$ \\
\hline \multirow{3}{*}{ Çokkültürlü } & Sabit & 2.51 & .29 & & 8.48 & .00 \\
eğitim & Sosyal bilgi süreci & .25 & .06 & .21 & 3.66 & $.00 *$ \\
& Sosyal beceri & .03 & .05 & .03 & .58 & .56 \\
& Sosyal farkındalık & .05 & .06 & .04 & .80 & .42 \\
\hline
\end{tabular}

$R=.24 R^{2}=.06, \mathrm{~F}(3-314)=6.746, \mathrm{p}<.05$

Tablo 6 incelendiğinde, sosyal bilgi sürecinin çokkültürlü eğitim tutumu ile anlamlı bir ilişki verdiği görülmektedir $(R=.24, p<.01)$. Bu yordayıcı değişkenler, öğretmenlerin çokkültürlü eğitim tutumuna ilişkin algılarındaki toplam varyansın \% 6'sını açıklamaktadır. Sosyal bilgi süreci $(\beta=.21$, $\mathrm{p}<.05$ ) çokkültürlü eğitim tutumunun anlamlı bir yordacısıdır. Diğer boyutlar ise anlamlı bir etki göstermemektedir. 


\section{TARTIŞMA, SONUÇ VE ÖNERILER}

Bu araştırmada ilköğretim ve ortaöğretim öğretmenlerin sosyal zekâ ve çokkültürlü eğitim tutum algıları çeşitli değişkenler açısından irdelenmiş ve kavramlar arasındaki ilişki incelenmiştir. Araştırmada ilk önce öğretmenlerin sosyal zekâ ve çokkültürlü eğitim tutumlarının nasıl olduğu değerlendirilmiştir. Bulgulara göre öğretmenlerin sosyal zekâ ve çokkültürlü eğitim tutum algıları görece yüksek düzeyde ve olumlu olarak tespit edilmiştir. Ayrıca araştırmada öğretmenlerin sosyal zekâ boyutlarına yönelik algıları büyükten küçüğe sosyal bilgi süreci, sosyal beceri ve sosyal farkındalık olarak sıralanmaktadır. Sosyal zekâ algısı ile ilgili bulgular; Doğan ve Çetin (2009), Doğan ve diğerleri (2009), illhan ve Çetin (2014), Silvera ve diğerleri (2001) ve Yahyazadeh-Jeloudar ve Lotfi-Goodarzi'nin (2012) çalışmaları ile desteklenmektedir. Özdemir ve Dil (2013), Tortop (2014), Yazıcı ve diğerlerinin (2009) çalışmaları da, mevcut araştırmada saptanan çokkültürlü eğitim tutum algı düzeyi ile uyumlu görülmüştür. Bu bulgular öğretmenlerin öğrencilerinin ne hissettiklerini anladıklarını ancak öğrencilerini anlamalarına rağmen etkili iletişim kurma ve uyum sağlama süreci konusunda sıkıntı yaşayabildikleri, düşüncelerini istedikleri gibi aktaramadıklarını gösteriyor olabilir. Ek olarak öğretmenlerin çokkültürlü eğitim tutumlarının olumlu yönde olması, öğrencilerinin kültürel farklılıklarının bilincinde olmaları, bu farklılıkların bir zenginlik olarak kabul edilmesi ve karşılıkı etkileşimden herkesin fayda sağlayacağı yönünde yorumlanabilir.

Araştırmada ikinci olarak, öğretmenlerin sosyal zekâ ve çokkültürlü eğitim tutumlarının çeşitli değişkenlere yönelik anlamlı değişiklikler gösterip göstermediği sorgulanmıştır. Bulgulara göre öğretmenlerin sosyal zekâ algıları cinsiyet, eğitim düzeyi ve okul türü değişkenlerine göre anlamlı farklııık göstermemiştir. Ancak, erkek öğretmenlerin kadınlara, lisansüstü eğitim alanların lisans eğitimi alanlara ve ilkokulda görev yapanların ortaokul ve lisede görev yapanlara göre görece daha yüksek sosyal zekâ algılarına sahip oldukları dikkat çekmektedir. Doğan ve diğerleri (2009) ve Silvera ve diğerlerinin (2001) üniversite öğrencileri örnekleminde yaptıkları çalışmasında da cinsiyet yönünden anlamlı farklılıklar saptanmamıştır. Ancak mevcut çalışma bulgularının aksine kadınların erkeklere göre sosyal zekâ algılarının daha yüksek olduğu belirlenmiştir. Destekler nitelikte Birknerová (2011) da, yöneticiler, öğretmenler ve öğrenciler örnekleminde cinsiyet açısından anlamlı farklılıklar bulamamıştır. Yahyazadeh-Jeloudar ve Lotfi-Goodarzi (2012) ise, çalışmalarında yüksek lisans mezunu öğretmenlerin lisans mezunlarına göre görece daha yüksek sosyal zekâ algısına sahip olduklarını saptamıştır. Anlamlı farklılıklar olmamakla beraber lisansüstü eğitim alan öğretmenlerin sosyal zekâ algı yüksekliğinin altındaki sebep eğitimsel farkındalık olabilir. Özellikle öğretmenlik mesleği insanlarla yoğun ilişkiler içerisinde bulunan bir meslek olduğu düşünüldüğünde daha yoğun bilgi içeren lisansüstü eğitim sürecinin, öğretmenlerin sosyal farkındalık ve becerilerini artırabileceği belirtilebilir. Illkokulda görev yapan öğretmenlerin sosyal zekâ algı düzeyi yüksekliği ise öğrenci ve velilerle olan daha yoğun ve doğrudan etkileşimin ürünü olabilir. ìlkokul öğretmenlerin çoğunlukla daha az öğrenci ile daha fazla zaman geçirmeleri öğrenciler ile öğretmenler arasında yüksek duygu paylaşımını destekleyebilir. Bu durumun öğretmenlerin öğrencileri daha iyi tanımalarını ve davranışlarını anlamaları üzerinde olumlu etkide bulunabileceği savunulabilir.

Öğretmenlerin çokkültürlü eğitim tutum algıları incelendiğinde cinsiyet ve eğitim düzeyi değişkenlerine göre anlamlı farklılıklar tespit edilmemiştir. Ancak erkek öğretmenlerin kadın öğretmenlere ve lisansüstü eğitim alan öğretmenlerin de lisans eğitimi alan öğretmenlere göre çokkültürlü eğitim tutum algılarının görece daha yüksek olduğu saptanmıştır. Özdemir ve Dil'in (2009) lise öğretmenleri örnekleminde gerçekleştirdikleri çalışmalarında cinsiyet ve eğitim düzeyi değişkenlerinin anlamlı farklılık göstermemesi mevcut çalışma bulgularını desteklemektedir. Farklı örneklemler üzerinde yapılan çalışmalarda Damgacı ve Aydın (2013) ve Tortop (2014) da cinsiyet yönünde anlamlı bir farklılık tespit edememiştir. Ancak, Demircioğlu ve Özdemir'in (2014) çalışmasında pedagojik formasyon öğrencilerinin, cinsiyet yönünden kadınlar lehine daha olumlu tutuma sahip oldukları belirlenmiştir. Lisansüstü eğitim alan öğretmenlerin çokkültürlü eğitim tutumunun görece yüksek olması, eğitime daha geniş bir perspektiften bakılıyor olmasından 
kaynaklanabilir. Özellikle daha yoğun ve derinlemesine bir eğitim süreci olan lisansüstü eğitimde farklılıklara duyarlılık göz ardı edilmeyen bir konudur. Küreselleşmenin de getirisi olarak farklılıkların toplumun bir unsuru olmasının kültürel zenginleşmeyi sağladığı düşünülebilir. Küreselleşme ile birlikte kültürler arası etkileşime yönelik bir hassasiyet ve bunun eğitim sürecine yansıması eğitimsel olarak daha yüksek bir noktada bulunan öğretmenlerin ilgisini çekiyor olabilir. Ayrıca okul türü değişkenine göre ilkokulda görev yapan öğretmenlerle ortaokul ve lisede görev yapan öğretmenlerin çokkültürlü eğitim tutum algıları arasında anlamlı farklııklar görülmüştür. illkokullarda görev yapan öğretmenlerin çokkültürlü eğitim tutumunun yüksek olması, öğrencilerle daha fazla vakit geçirerek sıcak ilişkilerin kurulmasının etkisiyle çeşitli kültürel ortamlardan olan öğrencilere yönelik farkındalıklarını yükseltmesinden kaynaklanıyor olabilir.

Araştırmada son olarak öğretmenlerin sosyal zekâ ve çokkültürlü eğitim tutumları arasındaki ilişki ve sosyal zekânın çokkültürlü eğitim tutumunun anlamlı bir yordayıcı olup olmadığı irdelenmiştir. Öğretmenlerin çokkültürlü eğitim tutumu ile sosyal zekâları arasında düşük düzeyde anlamlı ilişkiler mevcuttur. Çokkültürlü eğitim tutumu ile sosyal zekâ boyutları arasındaki en yüksek ilişki ise sosyal bilgi süreci boyutu ile gerçekleşmektedir. Ayrıca sosyal zekâ boyutlarının çokkültürlü eğitim tutumunun \% 6'sını açıkladığı ve sosyal bilgi sürecinin çokkültürlü eğitim tutumunun anlamlı bir yordayıcısı olduğu tespit edilmiştir. Araştırma öncesinde değişkenler arasında daha yüksek düzeyde bir ilişki düşünülmekteydi. Özellikle farklı kültürel ortamlardan gelen bireylerin intiyaçlarını ve gereksinimlerini fark edebilmek için kişilerarası ilişkileri anlayabilme, geliştirebilme ve etkili iletişim içerisinde olabilme farkındalığı ve becerisine sahip olunmasının gerektiği düşünülebilir. Ancak araştırma bulgularına göre beklenilenden daha düşük bir ilişki ortaya çıkmıştır. Öğretmenlik mesleği insanlarla iç içe geçmiş yoğun etkileşim barındıran özel bir meslektir. Öğrencilerin tutumlarını ve davranışlarını anlayabilmek ve buna yönelik eylemlerde bulunmak öğretmenlik mesleğinin önemli özelliklerinden birisidir. Öğretmenler öğrencileriyle geçirdikleri zaman içerisinde karşılıklı iletişim ve gözlemleri sonucunda onların ilgi, istek ve intiyaçları konusunda bilgi sahibi olabilmektedir. Özellikle sosyal zekâ boyutları arasında olan sosyal bilgi süreci öğretmenlerin çocukların hissettiklerini anlayabilme potansiyelini vurgulamaktadır. Bundan dolayı ilgili boyutun çokkültürlü eğitim tutumu üzerindeki etkisini anlamak daha olası görülmektedir.

Son söz olarak, araştırmada öğretmenlerin sosyal zekâ ve çokkültürlü eğitim tutum algılarının görece yüksek ancak orta düzeye yakın tespit edilmesi geliştirilmesi gereken bir konu olarak düşünülebilir. Eğitim kalitesinin yükselmesinde öğretmen öğrenci ilişkisinin önemi yadsınamaz. Öğretmenlerin, öğrencilerin bireysel özelliklerinin farkında olabilmeleri eğitim ortamını onlara en fazla fayda sağlayabilecek şekilde düzenlemelerine yardımcı olacaktır. Yapılandırmacı eğitim yaklaşımının temelinde yer alan öğrencinin daha aktif olmasının yolu bir bakıma öğretmenlerin farkındalık becerisine bağlıdır. Özellikle son yıllarda gerçekleşen dış göçlerin de etkisiyle, Türkiye kültürel olarak daha çeşitlilik gösteren bir yapıya bürünmüştür.

Araştırma sonuçlarına ilişkin aşă̆ıdaki öneriler geliştirilebilir;

1. Öğrenim gören öğretmen adayları ve mevcut öğretmenlerin çokkültürlü eğitim konusunda daha yoğun eğitimlerden geçirilmesinin kültürel uyum sürecinin daha kolay sağlanmasına ve etkili eğitim verilmesine hizmet edebileceği düşünülebilir.

2. Farklılıkların yönetimi konusunda okul yöneticilerine hizmet-içi eğitim verilebilir.

3. Benzer araştırmalar daha geniş örneklemlerde ve farklı kültürlerden öğrencilerin eğitim aldığı okullarda görev yapan öğretmenler ile gerçekleştirilerek geniş bir perspektiften karşılaştırmalı analizler yapılabilir.

4. Özellikle Suriyeli öğretmenler örnekleminde çokkültürlü eğitim yaklaşımı irdelenebilir.

5. Nitel ya da karma araştırma yöntemleri ile araştırma tekrar gerçekleştirilebilir. 


\section{Kaynakça}

Albrecht, K. (2006). Social Intelligence: The New Science of Success. San Francisco, CA: Jossey-Bass.

Aman, D. ve Verma, E. (2015). Metacognition Among Secondary School Students in Relation to Social Intelligence, Gender, Type of Family and Locale. GHG Journal of Sixth Thought, 2(2), 11 16.

Banks, J. (1989). Multicultural Education: Characteristics and Goals. in J. Banks \& C. Banks (Eds.), Multicultural Education: Issues And Perspectives. Boston: Allyn And Bacon.

Banks, J. A. (1991). The Dimensions of Multiculturale Education. Multicultural Leader, 4, 5-6.

Banks, J. A. (1993a). Multicultural Education: Developments, Dimensions, and Challenges. Phi Delta Kappan, 75, 22-28.

Banks, J. A. (2008). An introduction to Multicultural Education (4th Ed.). Boston, MA: Allyn \& Bacon.

Başbay, A. Ve Bektaş, Y. (2009). Çokkültürlülük Bağlamında Öğretim Ortamı ve Öğretmen Yeterlikleri. Eğitim ve Bilim, 34(152), 30-43.

Birknerová, Z. (2011). Social and Emotional Intelligence in School Environment. Asian Social Science, $7(10), 241-248$.

Birknerová, Z., Frankovský, M., ve Zbihlejová, L. (2013). Social Intelligence in The Context of Personality Traits of Teachers. American International Journal of Contemporary Research, 3(7), 11-17.

Brayboy, B. M. J. (2005). Toward A Tribal Critical Race Theory in Education. Urban Review, 37, 425446.

Buzan, T. (2002). The Power of Social Intelligence. Newyork, NY: Perfectpound Publisher.

Chauhan, J. M. (2016). Social Intelligence and Adjustment in Young Male And Female. International Research Journal, 1(1), 30-37.

Damgacı, F., Ve Aydın, H. (2013). Akademisyenlerin Çokkültürlü Eğitime Iliş̧in Tutumları. Elektronik Sosyal Bilimler Dergisi, 12(45), 325-341.

Davidman, L. ve Davidman, P. (1997). Teaching with A Multicultural Perspective: A Practical Guide. New York: Longman.

Demircioğlu, E. ve Özdemir, M. (2014). Pedagojik Formasyon Öğrencilerinin Çok Kültürlü Eğitime Yönelik Tutumlarının Bazı Değişkenlere Göre İncelenmesi. Ege Eğitim Dergisi, 15(1), 211-232.

Doğan, T. ve Çetin, B. (2009). Tromso Sosyal Zekâ Ölçeği Türkçe Formunun Faktör Yapısı, Geçerlik ve Güvenirlik Çalışması. Kuram ve Uygulamada Eğitim Bilimleri, 9(2), 691-720.

Doğan, T., Totan, T. ve Sapmaz, F. (2009). Üniversite Öğrencilerinde Benlik Saygısı ve Sosyal Zekâ. Sakarya Üniversitesi Eğitim Fakültesi Dergisi, 17, 235-247.

Dong, Q., Koper, R. J. ve Collaço, C. M. (2008). Social Intelligence, Selfesteem, and intercultural Communication Sensitivity. Intercultural Communication Studies, 17(2), 162-172.

Emmerling, R. J. ve Boyatzis, R. E. (2012). Emotional and Social Intelligence Competencies: Cross Cultural Implications. Cross Cultural Management: An International Journal, 19(1), 4-18.

Goleman, D. (1995). Emotional intelligence. New York: Bantam Books.

Goleman, D. (2006). Social Intelligence: The New Science of Human Relationships. London, England: Arrow Books.

Goodstein, R. E. (1984). An Investigation into Leadership Behaviors and Descriptive Characteristics Of Band Directors in The United States (Doctoral Dissertation, Arizona State University). Dissertation Abstracts International, 45(8A), 2433.

Gorski, P. C. (2006). Complicity with Conservatism: The De-Politicizing of Multicultural and Intercultural Education. Intercultural Education, 17(2), 163-177. 
Günay, R., Aydın, H. ve Koç Damgacı, F. (2015). Eğitim Fakültelerinde Görev Yapan Akademisyenlerin Çokkültürlü Eğitim Kavramına İlişkin Metaforik Algıları. Çankırı Karatekin Üniversitesi Sosyal Bilimler Enstitüsü Dergisi, 6(1), 291-312.

Hançer, M. ve Tanrısevdi, A. (2003). Sosyal Zekâ Kavramının Bir Boyutu Olarak Empati Ve Performans Üzerine Bir İnceleme. Cumhuriyet Üniversitesi, Sosyal Bilimler Dergisi, 27(2), 211 225.

Hatch, T. ve Gardner, H. (1993). Finding Cognition in the Classroom: An Expanded View of Human Intelligence. in G. Salomon (Ed.), Distributed Cognitions: Psychological and Educational Considerations. Learning in Doing: Social, Cognitive, and Computational Perspectives (Pp. 164187). New York: Cambridge University Press.

Irvine, J. J. (2012). Complex Relationships Between Multicultural Education and Special Education: An African American Perspective. Journal of Teacher Education, 63(4) 268-274.

IIlhan, M., ve Çetin, B. (2014). Sosyal ve Kültürel Zekâ Arasındaki İlişkinin Yapısal Eşitlik Modeli ile incelenmesi. Turkish Journal of Education, 3(2), 4-15.

Karasar, N. (1994). Bilimsel Araştırma Yöntemleri (6. Basım). Ankara: Araştırma Eğitim Danışmanlık Ltd. Şti.

Kaukainen, A., Bjorkqvist, K., Lagerspetz,, K. Osterman, K., Salmivalli, C. ve Rothberg, S. (1999). The Relationship Between Social Intelligence, Emphaty and Three Types of Agression. Aggressive Behaviour, 25, 81-89.

Kosmitzki, C. ve John, O. P. (1993). The Implict Use of Explicit Conceptions of Social İntelligence. Personality and Individual Differences, 15, 11-23.

Krishnamurthi, M. (2003). Assessing Multicultural İnitiatives in Higher Education Institutions. Assessment \& Evaluation in Higher Education, 28(3), 263-277.

Kumagai, A. K. ve Lypson, M. L. (2006). Beyond Cultural Competence: Critical Consciousness, Social Justice, and Multicultural Education. Academic Medicine, 84(6), 782-787.

Latsone, L. (2013). Socially Intelligent Intercultural. Education. Educational Research Journal, 28(1\&2), 145-162.

Lee, J. (1999). Social Intelligence: Flexibility and Complexity Are Distinct From Creativity. Unpublished Doctoral Dissertation, University of Notre Dame, Indiana, USA.

Lund, D. E. (2006). Waking Up The Neighbors: Surveying Multicultural and Antiracist Education in Canada, The United Kingdom, and The United States. Multicultural Perspectives, 8(1), 35-43.

Markopoulos, P., Ruyter, B., Privender, S., Ve Breemen, A. (2005). Case Study: Bringing Social Intelligence into Home Dialogue Systems. Interactions, July+August, 37-44.

Marlowe, H. A. (1986). Social Intelligence: Evidence for Multidimensionality and Construct Independence. Journal of Educational Psychology, 78(1), 52-58.

Nieto, S. (2000). Affirming Diversity: The Sociopolitical Context of Multicultural Education (3rd Ed.). New York, NY: Longman.

Obiakor, F. E. (2007). Multicultural Special Education: Effective Intervention for Today's Schools. Interventıon in School and Clinic, 42(3), 148-155.

Özdemir, M. ve Dil, K. (2013). Öğretmenlerin Çokkültürlü Eğitime Yönelik Tutumları: Çankırı İli Örneği. Ankara Üniversitesi Eğitim Bilimleri Fakültesi Dergisi, 46(2), 215-232.

Phipps, C. J. (2007). Social Intelligence: The Heart and Science of Human Relationships. Social Intelligence Styles, 1, 4-5.

Porter, A. C. ve Brophy, J. (1988). Synthesis of Research On Good Teaching: Insights from The Work of The Institute for Research on Teaching. Educational Leadership, 45(8), 74-85.

UNESCO (2004). Changing Teaching Practices: Using Curriculum Differentiation to Respond to Students' Diversity. Paris: UNESCO. 
Santamaria, L. J. (2014). Critical Change for The Greater Good: Multicultural Perceptions in Educational Leadership Toward Social Justice and Equity. Educational Administration Quarterly, 50(3) 347-391.

Silberman, M. (2000). Peoplesmart: Developing Your interpersonal intelligence. San Francisco, CA: Berrett- Koehler Publishers Inc.

Silvera, D. H., Martinussen, M. ve Dahl, T. I. (2001). Th E Tromso Social Intelligence Scale, A SelfReport Measure Of Social Intelligence. Scandinavian Journal Of Psychology, 42, 313-31.

Sleeter, C. E. ve Grant, C. (2003). Making Choices For Multicultural Education: Five Approaches to Race, Class and Gender (2nd Ed.). New York, NY: Wiley.

Thorndike, E. L. (1920). Intelligence And its Use. Harper's Magazine, 140, 227-235.

Tortop, H. S. (2014). Öğretmen Adaylarının Üstün Yetenekli ve Çok Kültürlü Eğitime ilişkin Tutumları. Üstün Yetenekliler Eğitimi Araştırmaları Dergisi, 2(2), 16-26.

Wallenius, M., Punamaki, R. ve Rimpela, A. (2007). Digital Game Playing and Direct and indirect Aggression in Early Adolescence: The Roles of Age, Social Intelligence, and Parent-Child Communication. Journal of Youth Adolescence, 36, 325-336.

Yahyazadeh-Jeloudar, S. ve Lotfi-Goodarzi, F. (2012). The Relationship Between Social intelligence and Job Satisfaction Among MA and BA Teachers. International Journal of Educational Science, 4(3), 209-213.

Yazıcl, S., Başol, G. ve Toprak, G. (2009). Öğretmenlerin Çokkültürlü Eğitim Tutumları: Bir Güvenirlik ve Geçerlik Çalışması. Hacettepe Üniversitesi Eğitim Fakültesi Dergisi, 37, 229-242.

Zaccaro, S. J., Gilbert, J. A., Thor, K. K. ve Mumford, M. D. (1991). Leadership and Social Intelligence: Linking Social Perspectiveness and Behavioral Flexibility to Leader Effectiveness. Leadership Quarterly, 2(4), 317-342.

Zirkel, S. (2000). Social intelligence: The Development and Maintenance of Purposive Behavior. The Handbook of Emotional Intelligence. San Francisco, CA: Jossey-Bass. 


\section{Extended Summary}

In the last quarter of twenty-first century, the schools has taken a wide variety of structures due to immigration and globalization. Student diversity will continue to grow while global or regional migration is increasing (UNESCO, 2004).In this case, multicultural education classeswill be in a multicultural world where have various ethnic backgrounds and cultures. In this environment, it will be needed people who feel the interests and needs of different individuals and have effective communication skills and have advanced social intelligence. Social intelligence is the ability to establish good relationships with people and points out the awareness on social dynamics. In this direction, it is important being aware of the social dynamic and to adopt a multicultural education approach in global society.

Multicultural education aims to be thedemocratic elements such as honesty, equality, social justice and critical awareness in society. In a way, multicultural education underlines the combination of cultural compliance with anti-racist education targets(Lund, 2006). According to Obiakor (2007), the multicultural education has an equalizing effect on special and traditional education. It seeks to raise the potential of all students to the highest level despite the cultural, linguistic, ethnic and socio-economic disparities. Albrecht (2006) describes the social intelligence as an ability for getting along well with others and persuading them to cooperate. Social intelligence reducing the conflict while cooperation is developing. In addition, it's transforming the polarization and narrow-mindedness to tolerance. According to the Markopoulos etc. (2005), socially intelligent behaviours show a variety of ability features such as courtesy, interaction, admitting mistakes, being curious and non-verbal understanding.

This study was designed with relational model. The data were obtained from 318 primary and secondary school teachers in 2015-2016 academic year. The research was performed on study group so thatsample wasn't determined. Reserach data was obtained by e-mail, social networking sites and forum sites. In the study, data collection tool consists of three parts. In the first part, teachers' demographic informationsas gender, education level and type of school was collected. In the second part, Tromso Social Intelligence Scale which consist of 21 items was used for determining the perceptions of teachers about social intelligence. The scale was adapted and performed about validity and reliability by Çetin and Doğan (2009). The last part of the data collection tool is Multicultural Education Attitude Scale which has 20 items. The scale was adopted by Başol and Toprak (2009). The data were analysed by SPSS 22.0 and LISREL 8.8. software packages.

According to the findings, the perceptions of teachers about social intelligence and multicultural education attitude were detected relatively high level and positive. These findings show that teachers understand what students feel. But the teachers may experience diffuculties about communicating effectively and in the adaptation process. In addition, the teachers who have positive perception about multicultural education attitude are aware of cultural diversity of students. The perceptions of teachers' about social intelligence isn't significant relationship according to gender, education level and school type. It was examined that the perceptions of teachers about multicultural education attitude isn't significant differences according to gender and education level. In addition, according to the school type, the perceptions of teachers who employed at primary and secondary schools about multicultural education attitude has signicifant differences. Also, there is significant relationships between multicultural education attitude and social intelligence. The highest relationship between multicultural education attitude and social intelligence dimensions is social information process dimension. Moreover, it was found that, social intelligence explains the $\% 6$ of multicultural education attitude and social information process is a significant predictor of multicultural education attitude.

In conclusion, the perceptions of teachers' about multicultural education attitude and social intelligence was identified relatively high level but close to the moderate level. This situation can 
be considered as an issue that needs to be improved. The teacher and student relationship is very important for improving the quality of education. Teachers' awareness about individual characteristics of students will help to shape educational environment for providing maximum benefits to them. The path of the constructivist approach to training students to be more active depends on the teachers' awareness skills. Especially in recent years, Turkey has a structure that more culturally diversity due to emigration. In this regard, it is recommended that, teachers should be taken more intensive training about the multicultural education. Thus, it's considered to facilitate the acculturation process and services could also be given effective training. Also similar researchesmay done in larger samples and performing comparative analysis from a broad perspective in the schoolswhich trained students from different cultures. 